\title{
From bench to bedside: Therapeutic potential of interleukin-9 in the treatment of asthma (Review)
}

\author{
FANG GONG, YU-HONG PAN, XUAN HUANG, HUA-YAN ZHU and DONG-LIN JIANG \\ Department of Respiratory Medicine, The Third Hospital Affiliated to Nantong University, \\ Wuxi, Jiangsu 214041, P.R. China
}

Received September 23, 2015; Accepted October 28, 2016

DOI: $10.3892 / e t m .2017 .4024$

\begin{abstract}
Initially identified as a $\mathrm{T}$ cell and mast cell growth factor, interleukin (IL)-9 has long been recognized as an important mediator of asthma. Recently, accumulating results from transgenic mice demonstrated that systemic or lung-specific overexpression of IL-9 caused asthma-associated symptoms. Moreover, anti-mIL-9 antibody (Ab) blocking treatment alleviated disease in animal models of asthma. In light of the large quantity of data from the murine models, MEDI-528, a humanized anti-IL-9 monoclonal Ab has been produced to assess the activity of IL-9 on human asthma. In order to ascertain whether it is a successful translation from bench to bedside, the biological features of IL-9 were evaluated and up-to-date information regarding the role of IL-9 in different experimental murine models and human asthma were summarized.
\end{abstract}

\section{Contents}

1. Introduction

2. IL-9 and IL-9 receptor structure

3. Signaling pathway

4. IL-9 in asthma

5. Targeting IL-9 in murine asthma models

6. Targeting IL-9 in human systems

7. Conclusion

\section{Introduction}

Asthma is characterized by recurrent and reversible airflow obstruction associated with airway hyperresponsiveness (AHR) and airway inflammation. Asthma currently affects

Correspondence to: Dr Fang Gong, Department of Respiratory Medicine, The Third Hospital Affiliated to Nantong University, 585 North Xingyuan Road, Wuxi, Jiangsu 214041, P.R. China E-mail: gongfang2004@163.com

Key words: interleukin-9, interleukin-9 receptor, asthma, allergic inflammation, treatment
300 million people worldwide, with a large socioeconomic burden (1). Until recently, the etiology and pathogenesis of asthma remained elusive. It is clear, however, that airway inflammation induced by the release of inflammatory cytokines is critical in the chronicity and progression of the disease (1).

Interleukin (IL)-9 belongs to a member of the four-helix bundle cytokine family. Initially identified as a $\mathrm{T}$ cell and mast cell growth factor, IL-9 has long been recognized as an important mediator of allergic inflammation $(2,3)$. A resurgence of interest in IL-9 has been spurred by recent work demonstrating its incremental targets and broader cellular sources (4). Indeed, in asthma, a series of experimental studies have demonstrated its diverse functions. Accumulating results from transgenic mice revealed that systemic or lung-specific overexpression of IL-9 caused an asthmatic phenotype, such as eosinophilic and lymphocyte inflammation, goblet cell hyperplasia, increased mucus production, increased immunoglobulin E (IgE) production, subepithelial collagen deposition and mast cell hyperplasia (5-7). Moreover, independent studies with anti-mIL-9 antibody (Ab) blocking treatment alleviated asthma-associated symptoms (8-11). In light of the profound effects that IL-9 has on various cells, and considering the large amount of data from the murine models, MEDI-528, a humanized anti-IL-9 monoclonal Ab has been produced to assess the activity of IL- 9 on human asthma (12-14).

In the present study the biological features of IL-9 will be discussed, with a focus on the role of IL-9 in different experimental murine models and human asthma.

\section{IL-9 and IL-9 receptor structure}

IL-9 is a 14-kDa glycoprotein consisting of 144 amino acids, including a signal sequence of 18 amino acids (15), and belongs to the four-helical cytokine family. The human IL-9 gene is located within the $\mathrm{T}$ helper (Th) 2 cytokine region on chromosome 5 (5q31-35), which also encodes IL-3, IL-4, IL-5, CD14 and granulocyte-macrophage colony-stimulating factor $(16,17)$. It has been reported that polymorphisms and linkage disequilibrium in this region have close associations with the development of asthma phenotype, including bronchial hyperresponsiveness, atopy and elevated total IgE levels (18-20). IL-9 was initially identified as a Th2 cytokine 
and numerous of the initial functions of IL-9 were examined in Th2-associated models. Later on, a specialized subset of T cells dedicated to producing IL-9 termed Th9 cells was reported $(21,22)$. Moreover, other Th subsets, including Th17, natural regulatory $\mathrm{T}$ cells also appear to have the potential for IL-9 production (23). Considering there are so many potential cellular sources of IL-9, the production and effect of IL-9 in vivo may be under a complicated regulation.

The IL-9 receptor (IL-9R), unlike IL-9, is a heterodimer. It is composed of the $\alpha$-chain (IL-9R $\alpha$ ) and the common $\gamma$-chain receptor shared by other cytokines including IL-2, IL-4, IL-7 and IL-15 $(24,25)$. Consistent with its pleiotropic functions, IL-9R is expressed on various cell types, including mast cells (26), macrophages (27), dendritic cells (28) and Th cell subsets Th2 and Th17 (29). Interestingly, genetic studies revealed that IL-9R is also associated with susceptibility to asthma (30-32). In 57 Caucasian families, Holroyd et al (30) provided evidence of linkage between a genomic region containing the IL-9R gene and asthma or AHR. Furthermore, haplotype analyses revealed that a specific haplotype (GAGC) had a protective effect against wheezing and against the development of sensitization (31). In addition, Melén et al (32) demonstrated that IL-9R (rs731476), in combination with IL-4 R $\alpha$ (rs1801275), exerts a major influence on susceptibility to asthma.

\section{Signaling pathway}

Janus kinase (JAK)/signal transducer and activator of the transcription (STAT) pathway is critical for signal transduction by IL-9/IL-9R. IL-9R $\alpha$ and the common $\gamma$-chain bind to JAK1 and JAK3, respectively (33). Moreover, ligation of IL-9R activates the JAK proteins phosphorylation. This leads to the downstream activation of STAT complexes. Consequently, STAT1, STAT-3 and STAT5 form homodimers, whereas STAT1 and STAT3 form heterodimers (34). Consequently, dimerized STAT molecules translocate to the nucleus, inducing the expression of effector genes. It was recently demonstrated that IL-9 induced JAK/STAT activation is crucial in cell proliferation, survival and secretion of inflammatory mediators $(35,36)$.

In addition, there are to some extent two more pathways involved in IL-9 signaling: The insulin receptor substrate (IRS)-phosphoinositide 3-kinase and Erk mitogen-activated protein kinase pathways (37). Although they are different from the JAK/STAT pathway, these two pathways appeared to be restricted to certain cell types (37). In several hematopoietic cell lines, IL-9 was reported to induce the phosphorylation of IRS-1 and IRS-2 (33). In addition, IL-9 was able to induce a transient phosphorylation of Erk 2 in the murine Th cell line TS1, the mast cell line MC9 and in $\mathrm{Ba} / \mathrm{F} 3$ and $32 \mathrm{D}$ cells transfected with the human IL-9 receptor (38). However, further investigation is required in order to determine the downstream effectors and the biological significance of these two signaling pathways.

\section{IL-9 in asthma}

It has been reported that IL- 9 concentrations increased in the bronchoalveolar lavage fluid (BALF) in the murine model of asthma (11). IL-9 expression has clearly been confirmed in BALF from atopic asthmatic patients using quantitative polymerase chain reaction and ELISA together with immunocytochemistry (39). Elevated levels of IL-9 have also been detected in lungs $(40,41)$, sputum (42) and serum (43) of asthmatic patients. Moreover, serum IL-9 levels were associated with the percentage of apoptotic eosinophils, which was recognized as a predominant feature of allergic asthma (43). Consistent with its initial identification as a mast cell growth factor, IL-9R is observed on mast and polymorphonuclear cells in the lungs of asthmatic individuals but not in healthy controls (44). These results also indicate a potential role of mast cells in asthma pathogenesis. Indeed, there is compelling evidence that an IL-9-mast cell axis is central to not only the acute symptoms of asthma but also the allergen-induced chronic inflammation (10).

\section{Targeting IL-9 in murine asthma models}

With these observations in mind, several investigators have studied targeting IL-9 as a therapy in murine asthma models since the late 1990s (5-11,45-49). Results from transgenic mice revealed that systemic or lung-specific overexpression of IL-9 caused an asthmatic phenotype, such as eosinophilic and lymphocyte inflammation, goblet cell hyperplasia, increased mucus production, increased IgE production, subepithelial collagen deposition and mast cell hyperplasia (Table I) (5-7). It is noteworthy that systemic IL-9 overexpressing transgenic mice only appear to exhibit the asthmatic phenotype after antigen exposure $(6,7)$, while unchallenged transgenic mice in the present study were relatively normal (6). By contrast, the transgenic mouse model of lung selective overexpression of IL-9 displayed massive airway inflammation, mast cell accumulation, increased subepithelial deposition of collagen and hyperresponsiveness without the presence of an antigen (5). The main reason for this discrepancy may be the difference between IL-9 expression levels, the location of IL-9-producing cells or possibly a more complicated temporal and spatial regulation involved in the IL-9 overexpressed mouse model. These data, appear to indicate that IL-9 may be a promising target for the treatment of patients with asthma. However, there are contradictions in the literature regarding the role of IL-9 in the fibrotic process. A study by Arras et al (45) revealed that the same systemic overexpression of IL-9 protects mice against alveolar fibrosis induced by silica. Additionally, an IL-9 intraperitoneal injection into C57BL/6 mice also reduced the amplitude of silica-induced lung fibr osis. Therefore, these data appear to indicate that IL-9 can either have an anti- or pro-fibrotic role in IL-9 overexpressing murine models of asthma, depending upon the localization of fibrosis and/or the varying effector cells involved. Consistent with the data from IL-9 overexpressing mice (FVB/N-TG5), two independent in vivo studies confirmed that intratracheal instillation of rmIL-9 into C57BL/6 mice increased eosinophils in the BAL and significantly elevated the total serum IgE (Table II) (46,47). Moreover, intratracheal administration of IL-9 significantly increased the levels of IL-5R $\alpha$ in the lung of B6 mice (46). Since several authors have linked the IL-5 and its receptor to the recruitment of eosinophils to the lung and since eosinophilic inflammation is a central feature 
Table I. Targeting the IL-9 gene in murine asthma models.

\begin{tabular}{|c|c|c|c|}
\hline Models & Antigen challenge & Results & Referenc \\
\hline FVB/N-TG5 & l & $\begin{array}{l}\text { Massive airway inflammation with eosinophils and lymphocytes, } \\
\text { increased numbers of mast cells within the airway epithelium, } \\
\text { epithelial cell hypertrophy associated with accumulation of } \\
\text { mucus-like material within nonciliated cells and increased } \\
\text { subepithelial deposition of collagen. }\end{array}$ & 5 \\
\hline FVB/N-TG5 & $\begin{array}{l}\text { Aspergillus } \\
\text { fumigatus }\end{array}$ & $\begin{array}{l}\text { TG5 mice display significantly enhanced eosinophilic airway } \\
\text { inflammation, elevated serum total IgE, and AHR following lung } \\
\text { challenge with a natural antigen. }\end{array}$ & 6 \\
\hline FVB/N-TG5 & Alternaria alternata & $\begin{array}{l}\text { There are more collagen fibers and eosinophils in the lung of Tg5 } \\
\text { mice. The concentration of the eosinophil chemoattractant RANTES } \\
\text { and the profibrotic mediator CTGF was higher in the BAL of } \\
\text { challenged Tg5 mice. }\end{array}$ & 7 \\
\hline FVB/N-TG5 & $\begin{array}{l}\text { Crystalline silica } \\
\text { particles }\end{array}$ & $\begin{array}{l}\text { The severity of fibrosis was significantly less important in } \operatorname{Tg} 5 \text { mice } \\
\text { than in their wild-type counterparts. }\end{array}$ & 45 \\
\hline IL-9 ${ }^{-/-}$BALB/c & OVA & $\begin{array}{l}\text { IL-9 knockout mice developed a similar degree of eosinophilic } \\
\text { inflammation and AHR to their wild-type littermates. Goblet cell } \\
\text { hyperplasia and IgE production were also unaffected. Moreover, } \\
\text { levels of IL-4, IL-5, and IL-13 in the BAL were comparable between } \\
\text { wild-type and knockout mice. }\end{array}$ & 48 \\
\hline IL-9 ${ }^{-/-}$BALB/c & OVA & IL-9 was not required for the bronchial accumulation of mast cells & 49 \\
\hline
\end{tabular}

IL, interleukin; OVA, ovalbumin; IgE, immunoglobulin E; AHR, airway hyperresponsiveness; CTGF, connective tissue growth factor; BAL, bronchoalveolar lavage.

of atopic asthma, it is conceivable that IL-9 also serves a significant role in eosinophilic inflammation in asthma.

However, in the IL-9-deficient mouse model, McMillan et al (48) revealed that IL-9 is not obligatory for the pathophysiological features of the allergic pulmonary response-AHR and eosinophilia. Goblet cell hyperplasia, sera total and ovalbumin (OVA)-specific IgE production and Th2 cytokines including IL-4, IL-5 and IL-13 levels in BAL were also unaffected by the lack of IL-9 (48). Data from Pae et al (49) also indicated that IL-9 was not required for the bronchial accumulation of mast cells. Collectively, these observations indicate that there are other alternative pathway substitutes for IL-9 in the development of asthma. Four independent studies with anti-mIL-9 Ab treatment in an OVA-sensitized mouse model revealed significantly reduced AHR, the numbers of eosinophils and lymphocytes, which resembles the classical features of asthma (Table II) (8-11). Discordance between published observations in IL-9 gene-deficient mice and an Ab blocking study may be attributable to protocol differences. As any knockout mice were generated during the embryonic stage, disruption of IL-9 at this early stage may have developed other adaptations.

\section{Targeting IL-9 in asthma patients}

Despite the conflicting results from murine models, the overall effects observed in these models indicated that targeting IL-9 might offer a novel approach to the treated patients with asthma. MEDI-528, a humanized anti-IL-9 monoclonal $\mathrm{Ab}$ has been produced to assess the activity of IL-9 on human asthma. Recently, MEDI-528 had been demonstrated with an acceptable safety profile and a linear pharmacokinetic (PK) profile when administered intravenously or subcutaneously (12-14).

In a phase IIa study, 36 mild asthma patients (18-65 years), enrolled to receive MEDI-528 (0.3, 1 and $3 \mathrm{mg} / \mathrm{kg}$ ) or placebo subcutaneously twice weekly for 4 weeks, revealed that MEDI-528 had no effect on the pulmonary function (13). However, another study in 9 adults (18-50 years) with stable, mild to moderate asthma and exercise-induced bronchoconstriction (EIB) received $50 \mathrm{mg}$ MEDI-528 or placebo subcutaneously twice weekly for 4 weeks, and indicated that blocking IL-9 with MEDI-528 may affect EIB (13). However, a statistical analysis could not be performed due to the limited small sample size. In order to further investigate whether anti-IL-9 monoclonal Ab has any clinical benefits in patients with asthma, a phase IIb study was performed (14). The double blind, multicenter, parallel-group study enrolled 329 adults randomized (1:1:1:1) to subcutaneous placebo or MEDI-528 (30, 100 and $300 \mathrm{mg}$ ) every 2 weeks for 24 weeks, in addition to their usual asthma medications. Failed to reach its primary endpoint, the results revealed that the addition of MEDI-528 to existing asthma controller medications was not associated with any improvement in the Asthma Control Questionnaire-6 scores, asthma exacerbation rates or FEV1 values. This observation may be surprising at the first 
Table II. Targeting IL-9 in murine asthma models.

\begin{tabular}{|c|c|c|c|c|}
\hline Model & $\begin{array}{l}\text { Antigen } \\
\text { challenge }\end{array}$ & Treatment & Results & Reference \\
\hline B6D2F1 & OVA & $\begin{array}{l}\text { Anti-IL-9 } \mathrm{mAb}(200 \mu \mathrm{g} / \text { mouse, i.p.) } \\
\text { was given } 2 \mathrm{~h} \text { before sensitization on } \\
\text { day } 1,5,9 \text {, and } 12 . \text { The last dose (on } \\
\text { day } 12) \text { was given } 2 \mathrm{~h} \text { before } \\
\text { antigen challenge. }\end{array}$ & $\begin{array}{l}\text { Treatment with anti-mIL-9 Ab significantly } \\
\text { reduced pulmonary eosinophilia, serum IgE } \\
\text { levels, goblet cell hyperplasia, airway epithelial } \\
\text { damage, and AHR, but had no effect on IL-4, } \\
\text { IL-5, and IL-13 mRNA levels in the lungs. }\end{array}$ & 8 \\
\hline $\mathrm{BALB} / \mathrm{c}$ & OVA & $\begin{array}{l}\text { Anti-IL-9 } \mathrm{mAb}(20 \mu \mathrm{g} / \text { mouse, i.v. }) \\
\text { was given } 30 \mathrm{~min} \text { before OVA } \\
\text { provocation. }\end{array}$ & $\begin{array}{l}\text { Treatment with anti-mIL-9 Ab significantly } \\
\text { prevented AHR. Blockade of IL-9 reduced } \\
\text { the numbers of eosinophils and lymphocytes } \\
\text { and the concentrations of IL-4, IL-5, and IL-13 } \\
\text { in BALF. Macrophage-derived cytokine } \\
\text { expression in the airways was also decreased } \\
\text { by IL-9 blockade. }\end{array}$ & 9 \\
\hline $\mathrm{BALB} / \mathrm{c}$ & OVA & $\begin{array}{l}\text { Anti-IL-9 mAb (250 } \mu \mathrm{g} / \text { mouse, i.p.) } \\
\text { was administered } 30 \mathrm{~min} \text { twice } \\
\text { during the first week (days } 19 \text { and } 23) \\
\text { and once weekly thereafter. }\end{array}$ & $\begin{array}{l}\text { Treatment with anti-mIL-9 Ab attenuates MC } \\
\text { numbers in the lung, airway remodeling, and } \\
\text { is associated with decreased expression of } \\
\text { VEGF, FGF-2, and TGF } \beta \text {. }\end{array}$ & 10 \\
\hline $\mathrm{BALB} / \mathrm{c}$ & OVA & $\begin{array}{l}\text { Anti-IL-9 mAb (100 } \mu \mathrm{g} / \text { mouse, i.p.) } \\
\text { was given once a week during the } \\
\text { OVA challenge. }\end{array}$ & $\begin{array}{l}\text { Numbers of eosinophils, neutrophils, B cells, } \\
\text { mast cells, and Th17 cells decreased after } \\
\text { administration of anti-IL-9 Ab. Total IgE, } \\
\text { IL-5, IL-9, and IL-17 levels were also lower } \\
\text { in the anti-IL-9 group. }\end{array}$ & 11 \\
\hline C57BL/6 & I & $\begin{array}{l}5 \mu \mathrm{g} / \text { mouse of rmIL- } 9 \text { in BSA and } \\
\text { saline solution }(20 \mu \mathrm{l}) \text { were } \\
\text { intratracheal instilled once each day } \\
\text { to B6 mice for } 10 \text { days. }\end{array}$ & $\begin{array}{l}\text { Murine trachea insertion of mIL-9 increased } \\
\text { eosinophils in the BAL and significantly } \\
\text { elevated serum total IgE. IL-9 was also } \\
\text { found to induce IL-5R } \alpha \text { in vivo and in vitro. }\end{array}$ & 46 \\
\hline C57BL/6 & I & $\begin{array}{l}5 \mu \mathrm{g} / \text { mouse of rmIL- } 9 \text { in BSA and } \\
\text { saline solution }(20 \mu \mathrm{l}) \text { were } \\
\text { intratracheal instilled once each day } \\
\text { to B6 mice for } 9 \text { days. }\end{array}$ & $\begin{array}{l}\text { Murine trachea tissue exhibited muc5ac } \\
\text { mRNA upregulation and increased numbers } \\
\text { of periodic acid Schiff/Alcian blue-positive } \\
\text { mucous cells. }\end{array}$ & 47 \\
\hline
\end{tabular}

IL, interleukin; Ab, antibody; OVA, ovalbumin; IgE, immunoglobulin E; AHR, airway hyperresponsiveness; CTGF, connective tissue growth. factor; BALF, bronchoalveolar lavage fluid; VEGF, vascular endothelial growth factor; FGF-2, fibroblast growth factor 2; TGF $\beta$, transforming growth factor beta; BSA, bovine serum albumin.

glance, since recent results obtained from phase IIa clinical studies, as well as earlier observations in mouse models indicated a potential role in asthma. The main reason for this discrepancy may be the influence of asthma subtype and the heterogeneous group of patients presented here and enrolled in the other studies. Thus, it is not surprising that the heterogeneous nature of asthma has received increasing attention recently, as identification of potential subgroups or personal characteristics is likely to be the primary determinant of the efficacy with therapeutics such as MEDI-528.

\section{Conclusion}

Since it was initially described in the late 1980s, major advances regarding the biology of IL-9 have been achieved. Data from both murine models and clinical trials are now accumulating to support the involvement of IL-9/IL-9R in asthma. Yet, the results from the clinical trials in humans with asthma reflect the heterogeneity of this disease. Therefore, the next challenge before developing successful therapies will be the detailed identification of a potential subphenotype of human asthma. Finally, the determination of whether the asthma phenotype and its underlying mechanisms will allow researchers to devise personalized and phenotype-specific therapies for asthma, remains to be investigated.

\section{Acknowledgements}

The research was supported by the National Natural Science Foundation of China (grant no. 81400021) and the Jiangsu Natural Science Foundation of China (grant no. BK20140125). 


\section{References}

1. Lambrecht $\mathrm{BN}$ and Hammad $\mathrm{H}$ : The immunology of asthma Nat Immunol 16: 45-56, 2015

2. Hültner L, Druez C, Moeller J, Uyttenhove C, Schmitt E, Rüde E, Dörmer P and Van Snick J: Mast cell growth-enhancing activity (MEA) is structurally related and functionally identical to the novel mouse T cell growth factor P40/TCGFIII (interleukin 9). Eur J Immunol 20: 1413-1416, 1990.

3. Uyttenhove C, Simpson RJ and Van Snick J: Functional and structural characterization of P40, a mouse glycoprotein with T-cell growth factor activity. Proc Natl Acad Sci USA 85: 6934-6938, 1988.

4. Goswami R and Kaplan MH: A brief history of IL-9. J Immunol 186: 3283-3288, 2011.

5. Temann UA, Geba GP, Rankin JA and Flavell RA: Expression of interleukin 9 in the lungs of transgenic mice causes airway inflammation, mast cell hyperplasia, and bronchial hyperresponsiveness. J Exp Med 188: 1307-1320, 1998.

6. McLane MP, Haczku A, van de Rijn M, Weiss C, Ferrante V, MacDonald D, Renauld JC, Nicolaides NC, Holroyd KJ and Levitt RC: Interleukin-9 promotes allergen-induced eosinophilic inflammation and airway hyperresponsiveness in transgenic mice. Am J Respir Cell Mol Biol 19: 713-720, 1998.

7. van den Brûle S, Heymans J, Havaux X, Renauld JC, Lison D, Huaux F and Denis O: Profibrotic effect of IL-9 overexpression in a model of airway remodeling. Am J Respir Cell Mol Biol 37: 202-209, 2007

8. Kung TT,Luo B,Crawley Y,Garlisi CG,Devito K, Minnicozzi M, Egan RW, Kreutner W and Chapman RW: Effect of anti-mIL-9 antibody on the development of pulmonary inflammation and airway hyperresponsiveness in allergic mice. Am J Respir Cell Mol Biol 25: 600-605, 2001.

9. Cheng G, Arima M, Honda K, Hirata H, Eda F, Yoshida N, Fukushima F, Ishii Y and Fukuda T: Anti-interleukin-9 antibody treatment inhibits airway inflammation and hyperreactivity in mouse asthma model. Am J Respir Crit Care Med 166: 409-416, 2002

10. Kearley J, Erjefalt JS, Andersson C, Benjamin E, Jones CP, Robichaud A, Pegorier S, Brewah Y, Burwell TJ, Bjermer L, et al: IL-9 governs allergen-induced mast cell numbers in the lung and chronic remodeling of the airways. Am J Respir Crit Care Med 183: 865-875, 2011.

11. Kim MS, Cho KA, Cho YJ and Woo SY: Effects of interleukin-9 blockade on chronic airway inflammation in murine asthma models. Allergy Asthma Immunol Res 5: 197-206, 2013.

12. White B, Leon F, White W and Robbie G: Two first-in-human, open-label, phase I dose-escalation safety trials of MEDI-528, a monoclonal antibody against interleukin-9, in healthy adult volunteers. Clin Ther 31: 728-740, 2009.

13. Parker JM, Oh CK, LaForce C, Miller SD, Pearlman DS, Le C, Robbie GJ, White WI, White B and Molfino NA; MEDI-528 Clinical Trials Group: Safety profile and clinical activity of multiple subcutaneous doses of MEDI-528, a humanized anti-interleukin-9 monoclonal antibody, in two randomized phase 2a studies in subjects with asthma. BMC Pulm Med 11: 14,2011 .

14. Oh CK, Leigh R, McLaurin KK, Kim K, Hultquist M and Molfino NA: A randomized, controlled trial to evaluate the effect of an anti-interleukin-9 monoclonal antibody in adults with uncontrolled asthma. Respir Res 14: 93, 2013.

15. Renauld JC, Goethals A, Houssiau F, Merz H, Van Roost E and Van Snick J: Human P40/IL-9. Expression in activated CD4 ${ }^{+} \mathrm{T}$ cells, genomic organization, and comparison with the mouse gene. J Immunol 144: 4235-4241, 1990.

16. van Leeuwen BH, Martinson ME, Webb GC and Young IG: Molecular organization of the cytokine gene cluster, involving the human IL-3, IL-4, IL-5 and GM-CSF genes, on human chromosome 5. Blood 73: 1142-1148, 1989.

17. Baldini M, Lohman IC, Halonen M, Erickson RP, Holt PG and Martinez FD: A Polymorphism* in the 5' flanking region of the CD14 gene is associated with circulating soluble CD14 levels and with total serum immunoglobulin E. Am J Respir Cell Mol Biol 20: 976-983, 1999.

18. Postma DS, Bleecker ER, Amelung PJ, Holroyd KJ, Xu J, Panhuysen CI, Meyers DA and Levitt RC: Genetic susceptibility to asthma-bronchial hyperresponsiveness coinherited with a major gene for atopy. N Engl J Med 333: 894-900, 1995 .
19. Noguchi E, Shibasaki M, Arinami T, Takeda K, Maki T, Miyamoto T, Kawashima T, Kobayashi K and Hamaguchi H: Evidence for linkage between asthma/atopy in childhood and chromosome 5q31-q33 in a Japanese population. Am J Respir Crit Care Med 156: 1390-1393, 1997.

20. Doull IJ, Lawrence S, Watson M, Begishvili T, Beasley RW, Lampe F, Holgate T and Morton NE: Allelic association of gene markers on chromosomes $5 \mathrm{q}$ and $11 \mathrm{q}$ with atopy and bronchial hyperresponsiveness. Am J Respir Crit Care Med 153: 1280-1284, 1996.

21. Dardalhon V, Awasthi A, Kwon H, Galileos G, Gao W, Sobel RA, Mitsdoerffer M, Strom TB, Elyaman W, Ho IC, et al: IL-4 inhibits TGF-beta-induced Foxp3 ${ }^{+} \mathrm{T}$ cells and, together with TGF-beta, generates IL- $9^{+}$IL- $10^{+}$Foxp3(-) effector T cells. Nat Immunol 9: 1347-1355, 2008.

22. Veldhoen M, Uyttenhove C, van Snick J, Helmby $H$, Westendorf A, Buer J, Martin B, Wilhelm C and Stockinger B: Transforming growth factor-beta 'reprograms' the differentiation of T helper 2 cells and promotes an interleukin 9-producing subset. Nat Immunol 9: 1341-1346, 2008.

23. Noelle RJ and Nowak EC: Cellular sources and immune functions of interleukin-9. Nat Rev Immunol 10: 683-687, 2010.

24. Renauld JC, Druez C, Kermouni A, Houssiau F, Uyttenhove C, Van Roost E and Van Snick J: Expression cloning of the murine and human interleukin 9 receptor cDNAs. Proc Natl Acad Sci USA 89: 5690-5694, 1992.

25. Russell SM, Johnston JA, Noguchi M, Kawamura M, Bacon CM, Friedmann M, Berg M, McVicar DW, Witthuhn BA, Silvennoinen $\mathrm{O}$, et al: Interaction of IL-2R beta and gamma c chains with Jak1 and Jak3: Implications for XSCID and XCID. Science 266: 1042-1045, 1994.

26. Hültner L, Kölsch S, Stassen M, Kaspers U, Kremer JP, Mailhammer R, Moeller J, Broszeit $\mathrm{H}$ and Schmitt E: In activated mast cells, IL-1 up-regulates the production of several Th2-related cytokines including IL-9. J Immunol 164: 5556-5563, 2000.

27. Druez C, Coulie P, Uyttenhove C and Van Snick J: Functional and biochemical characterization of mouse P40/IL-9 receptors. J Immunol 145: 2494-2499, 1990.

28. Mohamadzadeh M, Ariizumi K, Sugamura K, Bergstresser PR and Takashima A: Expression of the common cytokine receptor gamma chain by murine dendritic cells including epidermal Langerhans cells. Eur J Immunol 26: 156-160, 1996.

29. Elyaman W, Bradshaw EM, Uyttenhove C, Dardalhon V, Awasthi A, Imitola J, Bettelli E, Oukka M, van Snick J, Renauld JC, et al: IL-9 induces differentiation of TH17 cells and enhances function of FoxP $3^{+}$natural regulatory $\mathrm{T}$ cells. Proc Natl Acad Sci USA 106: 12885-12890, 2009.

30. Holroyd KJ, Martinati LC, Trabetti E, Scherpbier T, Eleff SM, Boner AL, Pignatti PF, Kiser MB, Dragwa CR, Hubbard F, et al: Asthma and bronchial hyperresponsiveness linked to the XY long arm pseudoautosomal region. Genomics 52: 233-235, 1998.

31. Melén E, Gullstén H, Zucchelli M, Lindstedt A, Nyberg F, Wickman M, Pershagen G and Kere J: Sex specific protective effects of interleukin-9 receptor haplotypes on childhood wheezing and sensitisation. J Med Genet 41: e123, 2004.

32. Melén E, Umerkajeff S, Nyberg F, Zucchelli M, Lindstedt A, Gullstén H, Wickman M, Pershagen G and Kere J: Interaction between variants in the interleukin-4 receptor alpha and interleukin-9 receptor genes in childhood wheezing: Evidence from a birth cohort study. Clin Exp Allergy 36: 1391-1398, 2006.

33. Demoulin JB, Uyttenhove C, Van Roost E, DeLestré B, Donckers D, Van Snick J and Renauld JC: A single tyrosine of the interleukin-9 (IL-9) receptor is required for STAT activation, antiapoptotic activity and growth regulation by IL-9. Mol Cell Biol 16: 4710-4716, 1996.

34. Demoulin JB, Uyttenhove C, Lejeune D, Mui A, Groner B and Renauld JC: STAT5 activation is required for interleukin-9-dependent growth and transformation of lymphoid cells. Cancer Res 60: 3971-3977, 2000.

35. Hornakova T, Staerk J, Royer Y, Flex E, Tartaglia M, Constantinescu SN, Knoops L and Renauld JC: Acute lymphoblastic leukemia-associated JAK1 mutants activate the Janus kinase/STAT pathway via interleukin-9 receptor alpha homodimers. J Biol Chem 284: 6773-6781, 2009.

36. Adamson AS, Collins K, Laurence A and O'Shea JJ: The current STATus of lymphocyte signaling: New roles for old players. Curr Opin Immunol 21: 161-166, 2009. 
37. Knoops L and Renauld JC: IL-9 and its receptor: From signal transduction to tumorigenesis. Growth Factors 22: 207-215, 2004.

38. Demoulin JB, Louahed J, Dumoutier L, Stevens M and Renauld JC: MAP kinase activation by interleukin-9 in lymphoid and mast cell lines. Oncogene 22: 1763-1770, 2003.

39. Erpenbeck VJ, Hohlfeld JM, Volkmann B, Hagenberg A, Geldmacher H, Braun A and Krug N: Segmental allergen challenge in patients with atopic asthma leads to increased IL-9 expression in bronchoalveolar lavage fluid lymphocytes. J Allergy Clin Immunol 111: 1319-1327, 2003.

40. Erpenbeck VJ, Hohlfeld JM, Discher M, Krentel H, Hagenberg A, Braun A and Krug N: Increased expression of interleukin-9 messenger RNA after segmental allergen challenge in allergic asthmatics. Chest 123 (3 Suppl): 370S, 2003.

41. Shimbara A, Christodoulopoulos P, Soussi-Gounni A, Olivenstein R, Nakamura Y, Levitt RC, Nicolaides NC, Holroyd KJ, Tsicopoulos A, Lafitte JJ, et al: IL-9 and its receptor in allergic and nonallergic lung disease: Increased expression in asthma. J Allergy Clin Immunol 105: 108-115, 2000.

42. Sherkat R, Yazdani R, Ganjalikhani Hakemi M, Homayouni V, Farahani R, Hosseini M and Rezaei A: Innate lymphoid cells and cytokines of the novel subtypes of helper $\mathrm{T}$ cells in asthma. Asia Pac Allergy 4: 212-221, 2014.

43. Hoppenot D, Malakauskas K, Lavinskienė S, Bajoriūnienė I, Kalinauskaitè V and Sakalauskas R: Peripheral blood Th9 cells and eosinophil apoptosis in asthma patients. Medicina (Kaunas) 51: 10-17, 2015.
44. Abdelilah S, Latifa K, Esra N, Cameron L, Bouchaib L, Nicolaides N, Levitt R and Hamid Q: Functional expression of IL-9 receptor by human neutrophils from asthmatic donors: Role in IL-8 release. J Immunol 166: 2768-2774, 2001.

45. Arras M, Huaux F, Vink A, Delos M, Coutelier JP, Many MC, Barbarin V, Renauld JC and Lison D: Interleukin-9 reduces lung fibrosis and type 2 immune polarization induced by silica particles in a murine model. Am J Respir Cell Mol Biol 24: 368-375, 2001.

46. Levitt RC, McLane MP, MacDonald D, Ferrante V, Weiss C, Zhou T, Holroyd KJ and Nicolaides NC: IL-9 pathway in asthma: New therapeutic targets for allergic inflammatory disorders. J Allergy Clin Immunol 103: S485-S491, 1999.

47. Reader JR, Hyde DM, Schelegle ES, Aldrich MC, Stoddard AM, McLane MP, Levitt RC and Tepper JS: Interleukin-9 induces mucous cell metaplasia independent of inflammation. Am J Respir Cell Mol Biol 28: 664-672, 2003.

48. McMillan SJ, Bishop B, Townsend MJ, McKenzie AN and Lloyd CM: The absence of interleukin 9 does not affect the development of allergen-induced pulmonary inflammation nor airway hyperreactivity. J Exp Med 195: 51-57, 2002.

49. Pae S, Cho JY, Dayan S, Miller M, Pemberton AD and Broide DH: Chronic allergen challenge induces bronchial mast cell accumulation in BALB/c but not $\mathrm{C} 57 \mathrm{BL} / 6$ mice and is independent of IL-9. Immunogenetics 62: 499-506, 2010. 